\title{
The heritage and cultural values of ancient Chinese maps
}

\author{
JIANG Lilii, ${ }^{1,2}$ LIANG Qizhang ${ }^{2},{ }^{*}$ QI Qingwen ${ }^{1,2}$, YE Yanjun ${ }^{3}$, LIANG Xun² \\ 1. State Key Laboratory of Resources and Environmental Information System, CAS, Beijing 100101, China; \\ 2. Institute of Geographic Sciences and Natural Resources Research, CAS, Beijing 100101, China; \\ 3. School of Earth Science and Engineering, Hebei University of Engineering, Handan 056038, Hebei, China
}

\begin{abstract}
Ancient Chinese cartography dates back to the Western Jin Dynasty in the third century. Cartography was initiated during this period by Pei Xiu, a minister and cartographic expert, who suggested six principles of cartography. Pei Xiu, who is known as the father of Chinese cartography, oversaw the completion of the "Yu Gong Regional Maps", along with 18 articles and the "Terrain Fangzhang Map" (AD 224-271). This led to a number of subsequent cartographic initiatives including the "Wooden Fangzhang Map" (an administrative map) which was completed by Xie Zhuang, a minister during the Southern Dynasties (AD 502-557), "Haineihuayi Tu" (Map of China and its neighbouring countries) (AD 730-805), drawn by Jia Dan, a cartographer of the Tang Dynasty, and "Shouling Tu" (an administrative map, AD 1031-1095), drawn by Shen Kuo, a scientist during the Northern Song Dynasty. Throughout the 16th century, ancient Chinese cartography developed continuously and cumulatively, and formed the specific characteristics of China ancient cartography. Although Western latitude-based and longitude-based mapping techniques introduced to China in AD 1460, the theories and methods of Chinese and Western mapping systems co-existed for over 400 years. The cultural heritage of Chinese cartography can be seen in many famous ancient Chinese maps, including astronomical figures and atlases (world, Chinese, regional, military, water conservancy, historical, and educational maps), charts, and maps of scenic spots. These have hitherto been kept in well-known archives and institutions across the world. They form an important part of the global cultural heritage of ancient maps and cartography. Given their high cultural value, these maps remain an important point of study. This paper provides a preliminary discussion on the rarity, application, and the historical, scientific, and artistic value of ancient Chinese maps.
\end{abstract}

Keywords: ancient map; historical cartography; map heritage; ancient cultural maps

\section{Introduction}

The earliest recorded map of China appears in "Shangshuluohao" (a historical book) of the

Received: 2016-08-24 Accepted: 2017-02-28

Foundation: National Natural Science Foundation of China, No.41101447; Basic Science-technological Special Working: Compilation of the National Atlases of the People's Republic of China (New Century Version), No.2013FY112800; Foundation Project of the Ministry of Science and Technology, China, No.2012FY120200

Author: Jiang Lili, PhD, specialized in cartography, GIS and remote sensing. E-mail: jiangll@igsnrr.ac.cn

"Corresponding author: Qi Qingwen, Professor, E-mail: qiqw@igsnrr.ac.cn 
Zhou Dynasty (11th century BC to 256 BC), which describes the legend of how Xiwangmu (Grand Old Lady of the West, a deity in ancient Chinese myths) awarded a map to Emperor Shun; in another version of the legend, "Hanshu Jiaosizhi" (a historic book) states that "Yu received gold of Jiumu to cast Jiuding, looking like Jiuzhou". This cast was called the Jiuding map, which could be considered the prototype of prehistoric administrative regional territory maps. A giant painting printed on rocks, i.e., Map of Settlements, was found in the Yunnan Cangyuan Wazu Autonomous County, and the Map of Hunting, which was carved on turtle shell, was found in the Anyang Garden Village of Henan (Yang et al., 2003). During the Three Kingdoms Period (AD 220-280), Madame Zhao was ordered to make the topographic embroidery map to defend the neighboring countries. During the Qin and Han periods, military maps already exhibited certain scientific mapping features based on measurements, such as proportion, distance, direction, and symbols. Therefore, by the time science became an established part of Chinese map making, ancient maps had already evolved and developed over a period of 1400 years.

Wang Qianjin, a famous geographer, suggested that the theory of cartography was based on six principles learned from the Qin and Han dynasties, although these were only recorded in written form by Pei Xiu (Wang et al., 2007). Because Pei went on to make the "Yu Gong Regional Maps" and the "Terrain Fangzhang Map", he was recognized as one of the creators of ancient scientific maps in China. Joseph Needham, a science historian from the United Kingdom, suggested that "Pei Xiu, the father of Chinese science of cartography, could be as famous as Ptolemy (the second century), a European ancient geographer." The 16-19th centuries witnessed the co-existence of Chinese cartography and Western technology, leading to a fusion of Chinese and Western maps; during this period, there was also a gradual modernization of Chinese cartography. The ancient Chinese cartographic theory and method, based on Pei Xiu's six principles of cartography, has been used since the mid-19th century. However, despite the many types of ancient scientific maps that have existed over 1600 years, few have been preserved until present day. In particular, few maps that were made before the Yuan Dynasty currently remain. Most of the maps stored in the National Library of China were made during the Ming or Qing Dynasty. Only a few maps from the Song Dynasty have been preserved because stone maps were prevalent in this period, and many other ancient maps from the Ming or Qing Dynasty have been retained overseas. Ancient Chinese cartography is an important record that aids researchers to explore nature and promote social progress. Wang Jiayao, a famous Chinese cartographer, said "Map is one of the cultural products that cannot be substituted with other information carriers" (Niu, 2014). Based on the ancient maps and related historical materials from the Western Jin to Qing Dynasties, compiled by the "Records of Modern Chinese Maps" Research Group, this paper discusses ancient heritage maps, early cartography heritage, and the cultural value of old maps. We hope to inspire more people to join in the protection and use of the heritage of ancient Chinese maps.

\section{The heritage of ancient Chinese maps}

The heritage of ancient Chinese maps includes the "Atlas of Ancient China" (three volumes, i.e., the Warring States Period to the Yuan Dynasty, Ming Dynasty, and Qing Dynasty) (Cao et al., 1990a; Cao et al., 1990b; Cao et al., 1997), "Selected Ancient Chinese Maps" (Liu, 1995), “Ancient Chinese Map of Treasure Anthology" (Yu, 1998), "map to be recorded and 
preserved in National Library of China" (Shanbentezang Group in Yutu Department of Beijing Library, 1997), "Atlas of Ancient China" (city map) (Zheng, 2005), "Descriptive Catalog of Antique Maps" preserved in the Library of Chinese Academy of Sciences (Sun, 2012), other representative maps available in the "Chinese Old Map Descriptive Catalog" (Li, 1996; Li, 2004), and other literature preserved abroad, covering maps of the world and of China, astronomical, nautical, sea/land defense and military, river and water conservancy, topographic, places of interest and historical sites, geologic and mineral resources, weather, education, and other thematic maps, as well as maps of the world continents, regions, and of Chinese counties. Based on their chronological development and technology, we divided these different types of ancient maps into three periods: 1) from the Western Jin Dynasty to Yuan Dynasty; 2) the Ming Dynasty; and 3) the Qing Dynasty. We then described the representative works, features, and value of each period. The most famous and precious maps of the world, the maps of China, and astronomical maps preserved in China and abroad, are listed in Tables 1 and 2.

Table 1 Typical ancient maps from the Western Jin Dynasty to Yuan Dynasty of China

\begin{tabular}{|c|c|c|c|c|c|}
\hline No & Name of map & Time (AD) & Type of map & Author & Collections \\
\hline 1 & $\begin{array}{l}\text { Yu Gong Regional } \\
\text { Maps (18) }\end{array}$ & AD 224-271 & $\begin{array}{l}\text { Historic Atlas (Yu to } \\
\text { Western Jin) }\end{array}$ & Pei Xiu & $\begin{array}{l}\text { Biography of Pei Xiu } \\
\text { Western Jin Dynasty }\end{array}$ \\
\hline 2 & $\begin{array}{l}\text { Terrain Fangzhang } \\
\text { Map }\end{array}$ & AD 224-271 & $\begin{array}{l}\text { Ancient Terrain Map } \\
(1: 1,800,000)\end{array}$ & Pei Xiu & $\begin{array}{l}\text { Biography of Pei Xiu } \\
\text { Western Jin Dynasty }\end{array}$ \\
\hline 3 & $\begin{array}{l}\text { Wooden Fangzhang } \\
\text { Map }\end{array}$ & AD 502-557 & $\begin{array}{l}\text { County map of Liang } \\
\text { Dynasty }\end{array}$ & Xie Zhuang & $\begin{array}{l}\text { Biography of Xie } \\
\text { Zhuang in History of } \\
\text { Southern Dynasties }\end{array}$ \\
\hline 4 & $\begin{array}{l}129 \text { volumes of } \\
\text { Quyutuzhi }\end{array}$ & AD 581-600 & $\begin{array}{l}\text { The first county chronicle } \\
\text { on unification of China }\end{array}$ & $\begin{array}{l}\text { Organized by } \\
\text { Emperor Sui }\end{array}$ & Historical records \\
\hline 5 & $\begin{array}{l}\text { Records of Maps of } \\
\text { Western Countries }\end{array}$ & AD 604-618 & 44 Western countries & Pei Ju & Historical records \\
\hline 6 & $\begin{array}{l}\text { States Atlas } 100 \\
\text { volumes }\end{array}$ & $\mathrm{AD} 615$ & $\begin{array}{l}\text { National Records of Sui } \\
\text { Dynasty }\end{array}$ & Sui Langmao & Historical records \\
\hline 7 & Haineihuayi Tu & AD 730-805 & $\begin{array}{l}\text { Map of China and its } \\
\text { neighboring countries }\end{array}$ & $\begin{array}{l}\text { Jia Dan, minister } \\
\text { of Tang Dynasty }\end{array}$ & $\begin{array}{l}\text { Biography of Jia Dan } \\
\text { in old history of Tang }\end{array}$ \\
\hline 8 & $\begin{array}{l}\text { Map of Yuanhejun } \\
\text { County }\end{array}$ & AD $805-820$ & $\begin{array}{l}\text { Geographical Records of } \\
\text { Tang Dynasty }\end{array}$ & $\begin{array}{l}\text { Li Jipu, Prime } \\
\text { Minister of Tang } \\
\text { Dynasty }\end{array}$ & Historical records \\
\hline 9 & Round Map* & AD 1020-1080 & Yu Map of Central Asia & $\begin{array}{l}\text { Mahmudde Kash- } \\
\text { galy }\end{array}$ & $\begin{array}{l}\text { National Library of } \\
\text { Istanbul }\end{array}$ \\
\hline 10 & $\begin{array}{l}\text { Map of Song Dy- } \\
\text { nasty }\end{array}$ & AD 1086-1093 & $\begin{array}{l}\text { County map of Song } \\
\text { Dynasty }\end{array}$ & $\begin{array}{l}\text { Mengxibitan, } \\
\text { Shen Kuo }\end{array}$ & $\begin{array}{l}\text { National Library of } \\
\text { China }\end{array}$ \\
\hline 11 & $\begin{array}{l}\text { Geographic map of } \\
\text { successive dynasties }\end{array}$ & AD 1098-1100 & Historic Atlas & $\begin{array}{l}\text { Shui Anli of } \\
\text { Northern Song }\end{array}$ & $\begin{array}{l}\text { National Library of } \\
\text { China }\end{array}$ \\
\hline 12 & Yu Map* & AD 1044-1130 & $\begin{array}{l}\text { Wooden map of geogra- } \\
\text { phy }\end{array}$ & $\begin{array}{l}\text { Huang Shang of } \\
\text { Northern Song }\end{array}$ & $\begin{array}{l}\text { An Atlas of Ancient } \\
\text { China }\end{array}$ \\
\hline 13 & $\begin{array}{l}\text { Stone carved } \\
\text { Astronomical Map } \\
\text { of Suzhou }\end{array}$ & AD 1044-1130 & $\begin{array}{l}\text { Astronomical map } \\
\text { (AD1190 stone carved) }\end{array}$ & $\begin{array}{l}\text { Huang Shang of } \\
\text { Northern Song }\end{array}$ & $\begin{array}{l}\text { Suzhou Museum of } \\
\text { Forest of Steles }\end{array}$ \\
\hline 14 & Map of Yuji & AD 1080-1094 & $\begin{array}{l}\text { Stone carved geographical } \\
\text { map (AD1136) }\end{array}$ & $\begin{array}{l}\text { Liu Yu carved in } 7 \\
\text { years of Fuchang }\end{array}$ & $\begin{array}{l}\text { Shaanxi Museum of } \\
\text { History }\end{array}$ \\
\hline 15 & $\begin{array}{l}\text { Terrain Map of } \\
\text { Western Xia* }\end{array}$ & AD1108 & Geographical map & $\begin{array}{l}\text { Wanli of Ming } \\
\text { Dynasty }\end{array}$ & $\begin{array}{l}\text { National Library of } \\
\text { China }\end{array}$ \\
\hline 16 & $\begin{array}{l}\text { Map of Jiuyu- } \\
\text { shouli* }\end{array}$ & $\begin{array}{l}\text { AD 1121/ } \\
\text { Northern Song }\end{array}$ & $\begin{array}{l}\text { County map of Song } \\
\text { Dynasty }\end{array}$ & $\begin{array}{l}\text { Song Changzong } \\
\text { of Northern Song }\end{array}$ & Sichuan Museum \\
\hline 17 & Huayi Tu & $\begin{array}{l}\text { Drawn from } \\
1117 \text { to } 1125 \\
\text { /Carved in } 1136\end{array}$ & $\begin{array}{l}\text { Stone carved geographical } \\
\text { map }\end{array}$ & Haineihuayi Map & Shaanxi Museum \\
\hline 18 & Liujingtubei* & 1155 & $\begin{array}{l}\text { Historic evolution map } \\
\text { carved on tablet }\end{array}$ & $\begin{array}{l}\text { Yang Jia of } \\
\text { Southern Song } \\
\text { Dynasty }\end{array}$ & $\begin{array}{l}\text { National Library of } \\
\text { China }\end{array}$ \\
\hline
\end{tabular}


(Continued)

\begin{tabular}{|c|c|c|c|c|c|}
\hline No & Name of map & Time (AD) & Type of map & Author & Collections \\
\hline 19 & $\begin{array}{l}\text { Geographic Maps of } \\
15 \text { countries* }\end{array}$ & 1165 & Historic evolution map & $\begin{array}{l}\text { Yang Jia of } \\
\text { Southern Song } \\
\text { Dynasty }\end{array}$ & $\begin{array}{l}\text { National Library of } \\
\text { China }\end{array}$ \\
\hline 20 & $\begin{array}{l}\text { Geographic Map of } \\
\text { China * }\end{array}$ & 1177 & Historic evolution atlas & $\begin{array}{l}\text { Cheng Dachang } \\
\text { of Southern Song } \\
\text { Dynasty }\end{array}$ & $\begin{array}{l}\text { National Library of } \\
\text { China }\end{array}$ \\
\hline 21 & $\begin{array}{l}\text { Geographic Map of } \\
\text { Qidan* }\end{array}$ & 1180 & Qidan administrative map & $\begin{array}{l}\text { Ye Longli of } \\
\text { Southern Song }\end{array}$ & $\begin{array}{l}\text { National Library of } \\
\text { China }\end{array}$ \\
\hline 22 & Map of Zhuili * & $\begin{array}{l}\text { Painted in } 1190 / \\
\text { inscribed on sto- } \\
\text { ne tablet in } 1247\end{array}$ & $\begin{array}{l}\text { Geographic map of Song } \\
\text { Dynasty }\end{array}$ & $\begin{array}{l}\text { Huang Shang of } \\
\text { Southern Song }\end{array}$ & $\begin{array}{l}\text { Stone tablets Mu- } \\
\text { seum in Suzhou }\end{array}$ \\
\hline 23 & Atlas of Empires & 1201 & Tupu liujing book & $\begin{array}{l}\text { Tang Zhongyou of } \\
\text { Southern Song }\end{array}$ & $\begin{array}{l}\text { National Library of } \\
\text { China }\end{array}$ \\
\hline 24 & $\begin{array}{l}\text { Administrative Map } \\
\text { of Shaanxi* }\end{array}$ & 1214 & $\begin{array}{l}\text { Administrative map of Jin } \\
\text { Dynasty (1187) }\end{array}$ & Shaanxi & \\
\hline 25 & $\begin{array}{l}\text { Attached map of } \\
\text { Record of Vernal } \\
\text { and Autumnal and } \\
\text { equinox* }\end{array}$ & $1205-1243$ & $\begin{array}{l}\text { Historic evolution map } \\
\text { (14) }\end{array}$ & $\begin{array}{l}\text { Chenggong of } \\
\text { Song Dynasty }\end{array}$ & $\begin{array}{l}\text { Sikuquanshu } \\
\text { (Wenyuange of } \\
\text { Taiwan) }\end{array}$ \\
\hline 26 & Yu Map & 1315 & $\begin{array}{l}\text { Terrestrial map of China } \\
\text { (including neighboring } \\
\text { countries) }\end{array}$ & Zhu Siben & $\begin{array}{l}\text { Hongxian Luo } \\
\text { (Guangyu Tu) }\end{array}$ \\
\hline 27 & $\begin{array}{l}\text { Shengjiaoguangbei } \\
\text { Map }\end{array}$ & Yuan Dynasty & $\begin{array}{l}\text { Terrestrial map of Yuan } \\
\text { Dynasty }\end{array}$ & Li Zemin & Original map \\
\hline 28 & Hunyijiangli map & Yuan Dynasty & $\begin{array}{l}\text { Terrestrial map of Yuan } \\
\text { Dynasty }\end{array}$ & Qing Jun & Original map \\
\hline 29 & Guangyujiangli map & 1360 & $\begin{array}{l}\text { Terrestrial map of Yuan } \\
\text { Dynasty }\end{array}$ & Qing Jun & $\begin{array}{l}\text { Ye Sheng (Shuidong } \\
\text { Diary) }\end{array}$ \\
\hline
\end{tabular}

Note: The symbol “*” indicates maps published in the "An Atlas of Ancient Maps of China"

\subsection{Ancient maps from the Western Jin Dynasty to the Yuan Dynasty - Perfection and origin of ancient Chinese cartography}

\subsubsection{Pei Xiu’s "Yu Gong Regional Maps" and "Terrain Fangzhang Map"}

After completing the "Yu Gong Regional Map" and "Terrain Fangzhang Map", Pei Xiu (AD 224-271) proposed "six principles of mapping", which opened the road for Chinese cartography. The "Yu Gong Regional Maps" constitutes a historical atlas focusing on political district boundaries. From "Yu Gong" to the Western Jin Dynasty, this atlas includes the ancient Kyushu, and the 16 states of the Western Jin Dynasty, shows the states, prefectures, counties, towns, and the boundaries between them; it also shows the mountains, plains, oceans, rivers, lakes, marshes, and other natural geographic features, and contains the history of major political events, the sea and land transport routes. "Terrain Fangzhang Map" used the "grid scales of $l i$ " law (Lu, 2008).

\subsubsection{Xie Zhuang led the production of the "Wooden Fangzhang Map"}

Based on cartographic theory, Xie Zhuang (AD 502-557), a minister in the Southern Dynasties, made a "Wooden Fangzhang Map". The map was spliced together using a number of block diagrams; when each diagram is separate, it represents the maps of the county, but when placed together these become a map of China. This made it an innovative map that was easy to carry.

\subsubsection{Cui Ji (Sui Dynasty) made the "Quyutuzhi"}

Records of the Sui Dynasty (AD 581-600) state that the Emperor Suiyang ordered to make county maps to understand the whole situation. Yu Shiji recommended Cui Ji to make the 
Table 2 Typical ancient maps from the Ming and Qing dynasties of China

\begin{tabular}{|c|c|c|c|c|c|}
\hline No & Name of map & Time (AD) & Type & Author & Collections \\
\hline 1 & Daminghunyi Map & 1389 & Map of China & unknown & $\begin{array}{l}\text { The First Historical } \\
\text { Archives of China }\end{array}$ \\
\hline 2 & Map of China & $\begin{array}{l}\text { 1418(Original } \\
\text { map) }\end{array}$ & $\begin{array}{l}\text { Double hemisphere } \\
\text { map }\end{array}$ & $\begin{array}{l}\text { Copied by Mo } \\
\text { Yitong (1763) }\end{array}$ & $\begin{array}{l}\text { Liu Gang, folk } \\
\text { collector }\end{array}$ \\
\hline 3 & $\begin{array}{l}\text { Charts of Zheng He's } \\
\text { Voyages* }\end{array}$ & 1430 & Ocean sailing map & Zheng He fleet & Peking Library \\
\hline 4 & $\begin{array}{l}\text { China Map of Ming Dy- } \\
\text { nasty }\end{array}$ & 1461 & $\begin{array}{l}\text { China map of Ming } \\
\text { Dynasty (atlas) }\end{array}$ & Li Xian, Wan An & $\begin{array}{l}\text { Peking University } \\
\text { Library }\end{array}$ \\
\hline 5 & Yangziqibayudi Map & 1512 & $\begin{array}{l}\text { China map of Ming } \\
\text { Dynasty }\end{array}$ & Yang Ziqi & $\begin{array}{l}\text { Beijing Luxun Mu- } \\
\text { seum }\end{array}$ \\
\hline 6 & Huangmingyu Map & 1529 & $\begin{array}{l}\text { China map of Ming } \\
\text { Dynasty }\end{array}$ & Gui E & Peking Library \\
\hline 7 & Wanlihaifang Map & $1530-1563$ & Coastal defense atlas & Zheng Ruozeng & Library of Congress \\
\hline 8 & Jiubian Map (copy)* & 1534 & $\begin{array}{l}\text { Military map (Land } \\
\text { defense map) }\end{array}$ & $\begin{array}{l}\text { Military depart- } \\
\text { ment (Xu Lun) }\end{array}$ & China History Museum \\
\hline 9 & Guangyu Map* & $1553-1557$ & Atlas of China & Luo Hongxian & Peking Library \\
\hline 10 & Chouhai Map & 1561 & Coastal defense map & Zheng Ruozeng & Peking Library \\
\hline 11 & Notes of Geography & 1564 & Atlas of China & $\begin{array}{l}\text { Xu Xiongzhi, Xu } \\
\text { Weishi }\end{array}$ & $\begin{array}{l}\text { Chinese Academy of } \\
\text { Sciences Library }\end{array}$ \\
\hline 12 & $\begin{array}{l}\text { China Map - Ancient and } \\
\text { modern figures' deeds* }\end{array}$ & 1593 & Map of the world & $\begin{array}{l}\text { Liang Zhou } \\
\text { (China traditional } \\
\text { painting) }\end{array}$ & $\begin{array}{l}\text { Collected by Philip } \\
\text { Robinson in England }\end{array}$ \\
\hline 13 & $\begin{array}{l}\text { China Map of Wang } \\
\text { Banshi* }\end{array}$ & 1594 & Map of China & No author & $\begin{array}{l}\text { The National Library } \\
\text { of France }\end{array}$ \\
\hline 14 & Kunyuwanguo Map* & 1602 & $\begin{array}{l}\text { Map of the world } \\
\text { (oval) }\end{array}$ & Matteo Ricci et al. & $\begin{array}{l}\text { University of Minne- } \\
\text { sota Library }\end{array}$ \\
\hline 15 & China Map* & 1602 & $\begin{array}{l}\text { Military map (land } \\
\text { defense map) }\end{array}$ & Shen Yongmao & China History Museum \\
\hline 16 & $\begin{array}{l}\text { China Coastal Defense } \\
\text { Map (copy)* }\end{array}$ & 1605 & $\begin{array}{l}\text { Coastal defense map } \\
\text { (atlas) }\end{array}$ & Dong Kewei & $\begin{array}{l}\text { China First Historical } \\
\text { Archives }\end{array}$ \\
\hline 17 & Liangyixuanzang Map* & 1603 & $\begin{array}{l}\text { Map of the world } \\
\text { (eight maps) }\end{array}$ & Li Yingshi & Liaoning Museum \\
\hline 18 & $\begin{array}{l}\text { Kunyuwanguo Map } \\
\text { (copy)* }\end{array}$ & 1608 & Map of the world & $\begin{array}{l}\text { Eunuch of Ming } \\
\text { Dynasty }\end{array}$ & Nanjing Museum \\
\hline 19 & Sancaituhui* & 1609 & Map of China & $\begin{array}{l}\text { Wang Qi, Wang } \\
\text { Siyi }\end{array}$ & $\begin{array}{l}\text { National Library of } \\
\text { China }\end{array}$ \\
\hline 20 & $\begin{array}{l}\text { East and west Hemi- } \\
\text { Sphere Map (Fangyu- } \\
\text { shenglue attached map)* }\end{array}$ & 1610 & $\begin{array}{l}\text { Double hemisphere } \\
\text { map of the world }\end{array}$ & Cheng Baier & Peking Library \\
\hline 21 & Wubei Zhi & 1621 & $\begin{array}{l}\text { Synthetic book on art } \\
\text { of the war }\end{array}$ & Mao Yuanyi & $\begin{array}{l}\text { National Library of } \\
\text { China }\end{array}$ \\
\hline 22 & Globe* & 1623 & Globe in Chinese & $\begin{array}{l}\text { Yang Manuo, Long } \\
\text { Huamin }\end{array}$ & British Museum \\
\hline 23 & Huangmingzhifang Map* & 1636 & Atlas of China & Chen Zushou & $\begin{array}{l}\text { National Library of } \\
\text { China }\end{array}$ \\
\hline 24 & $\begin{array}{l}\text { Border Map, Coastal } \\
\text { Defense Map }\end{array}$ & 1639 & Map of the world & Gu Yanwu & $\begin{array}{l}\text { National Library of } \\
\text { China }\end{array}$ \\
\hline 25 & $\begin{array}{l}\text { Atlas and Geographical } \\
\text { Description of Ming } \\
\text { Empire* }\end{array}$ & 1643 & Atlas of China & $\begin{array}{l}\text { Wu Xueyan, Zhu } \\
\text { Shaoben }\end{array}$ & $\begin{array}{l}\text { National Library of } \\
\text { China }\end{array}$ \\
\hline 26 & Historical Atlas of China* & 1643 & Historical Atlas & $\begin{array}{l}\text { Wu Guofu, Shen } \\
\text { Dingzhi }\end{array}$ & $\begin{array}{l}\text { Library of US Con- } \\
\text { gress }\end{array}$ \\
\hline 27 & World Map* & 1644 & Map of the world & Cao Junyi & Peking Library \\
\hline 28 & World Map & 1674 & Map of the world & Nan Huairen & $\begin{array}{l}\text { Hebei University } \\
\text { Library }\end{array}$ \\
\hline 29 & China Map & 1705 & $\begin{array}{l}\text { China map of Kangxi } \\
\text { Era }\end{array}$ & $\mathrm{Hu}$ Wei & \\
\hline 30 & $\begin{array}{l}\text { Complete Map of the } \\
\text { Empire of Kangxi's Reign }\end{array}$ & 1718 & Map of China & Du Demei & $\begin{array}{l}\text { National Library of } \\
\text { China }\end{array}$ \\
\hline 31 & Pengtai Nautical Chart & $1714-1722$ & Nautical chart & Unknown & Lushun Museum \\
\hline 32 & Yongzhengshipai Tu & 1726 & Map of China & $\begin{array}{l}\text { Chinese and West- } \\
\text { erns }\end{array}$ & $\begin{array}{l}\text { Chinese Academy of } \\
\text { Sciences Library }\end{array}$ \\
\hline 33 & Full View Map of Coast & 1731 & $\begin{array}{l}\text { Coastal defense map } \\
\text { of China }\end{array}$ & Chen Lunjiong & Nanjing Museum \\
\hline
\end{tabular}


(Continued)

\begin{tabular}{|c|c|c|c|c|c|}
\hline No & Name of map & Time(AD) & Type & Author & Collections \\
\hline 34 & $\begin{array}{l}\text { Fengzhouchuyang } \\
\text { shunfengzhenlu }\end{array}$ & 1756 & $\begin{array}{l}\text { Navigation map } \\
\text { (From Fuzhou to Liuqiu) }\end{array}$ & No annotated & Beijing Library \\
\hline 35 & Kunyu Map & 1760 & Map of the world & Jiang Youren et al. & $\begin{array}{l}\text { The first Historical } \\
\text { Archives of China }\end{array}$ \\
\hline 36 & $\begin{array}{l}\text { Shisanpai Map of } \\
\text { Qianlong's Reign }\end{array}$ & 1761 & Map of China & Jiang Youren et al. & Palace Museum \\
\hline 37 & Ancient Map of Taiwan & 1787 & Map of Taiwan & & $\begin{array}{l}\text { Anthropology Museum } \\
\text { of Xiamen University / } \\
\text { National Central Li- } \\
\text { brary in Taipei }\end{array}$ \\
\hline 38 & $\begin{array}{l}\text { Coastal Map of Seven } \\
\text { Provinces }\end{array}$ & $1787-1795$ & $\begin{array}{l}\text { China coastal defense } \\
\text { map }\end{array}$ & Chen Lunjiong & $\begin{array}{l}\text { China Historical } \\
\text { Museum }\end{array}$ \\
\hline 39 & $\begin{array}{l}\text { General Map of Qian- } \\
\text { weihoucang }\end{array}$ & 1798 & China Tibet Map & $\begin{array}{l}\text { Concise map of } \\
\text { Xizhao (attached) }\end{array}$ & $\begin{array}{l}\text { Chinese Academy of } \\
\text { Sciences Library }(1827)\end{array}$ \\
\hline 40 & $\begin{array}{l}\text { A complete Map of } \\
\text { Qing Dynasty }\end{array}$ & 1800 & Atlas of China & $\begin{array}{l}\text { Huang Zhengsun } \\
\text { (Qing Dynasty) }\end{array}$ & $\begin{array}{l}\text { National Mapping } \\
\text { Information Archives }\end{array}$ \\
\hline 41 & Canal Map & $1821-1825$ & China Grand Canal Map & No annotated & Peking Library \\
\hline 42 & $\begin{array}{l}\text { Map of United Country } \\
\text { of the Qing Dynasty }\end{array}$ & 1832 & $\begin{array}{l}\text { Map of China of Qing } \\
\text { Daoguang's Reign }\end{array}$ & $\begin{array}{l}\text { Li Zhaoluo, Dong } \\
\text { Fangli }\end{array}$ & Peking Library \\
\hline 43 & $\begin{array}{l}\text { Map of Historical } \\
\text { Geography }\end{array}$ & $1822-1837$ & $\begin{array}{l}\text { Historical Atlas } \\
\text { (Ming Dynasty) }\end{array}$ & Liu Yan & $\begin{array}{l}\text { Chinese Academy of } \\
\text { Sciences Library }\end{array}$ \\
\hline 44 & $\begin{array}{l}\text { Illustrated Record of } \\
\text { Maritime Nations }\end{array}$ & $1842-1852$ & $\begin{array}{l}\text { Atlas of the world } \\
\text { ( } 75 \text { sheets) }\end{array}$ & $\begin{array}{l}\text { Wei Yuan, Lin } \\
\text { Zexu }\end{array}$ & $\begin{array}{l}\text { Institute of Geographic } \\
\text { Sciences and Natural } \\
\text { Resources Research } \\
\text { Library }\end{array}$ \\
\hline 45 & $\begin{array}{l}\text { Complete Atlas of the } \\
\text { Imperial Domain }\end{array}$ & 1844 & Map of China & Zou Boqi & \\
\hline 46 & Wanguodadi Tu & 1845 & Map of the world & Ye Zipei & $\begin{array}{l}\text { Shijiazhuang Museum } \\
\text { in Hebei Province }\end{array}$ \\
\hline 47 & $\begin{array}{l}\text { Island Maps of Pacific } \\
\text { Ocean ( } 38 \text { sheets) }\end{array}$ & 1848 & $\begin{array}{l}\text { Yinghuanzhilue, attached } \\
\text { map }\end{array}$ & Xu Jiyu & National Library \\
\hline 48 & $\begin{array}{l}\text { Atlas of the Great Qing } \\
\text { Dynasty }\end{array}$ & 1863 & Map of China & Hu Linyi et al. & National Library \\
\hline 49 & $\begin{array}{l}\text { Complete Map of Qing } \\
\text { Dynasty }\end{array}$ & 1863 & $\begin{array}{l}\text { China atlas of Tongzhi in } \\
\text { Qing Dynasty }\end{array}$ & $\begin{array}{l}\text { Hu Linyi, Yan } \\
\text { Shusen }\end{array}$ & $\begin{array}{l}\text { National Mapping } \\
\text { Information Archives }\end{array}$ \\
\hline 50 & $\begin{array}{l}\text { Historical Map of } \\
\text { Successive Dynasties }\end{array}$ & 1863 & Historical Atlas & Yang Shoujing & $\begin{array}{l}\text { National Mapping } \\
\text { Information Archives }\end{array}$ \\
\hline 51 & $\begin{array}{l}\text { Map of World Conti- } \\
\text { nents }\end{array}$ & 1875 & Map of the world & Kuang Qizhao & $\begin{array}{l}\text { China Map Publishing } \\
\text { Group }\end{array}$ \\
\hline 52 & Wanguo Tu & 1886 & Map of the world & Chen Zhaotong & $\begin{array}{l}\text { China Map Publishing } \\
\text { Group }\end{array}$ \\
\hline 53 & $\begin{array}{l}\text { Map of United Country } \\
\text { of the Qing Dynasty }\end{array}$ & 1898 & $\begin{array}{l}\text { Map of China (Guangxu's } \\
24 \text { years of Qing Dynasty) }\end{array}$ & Liu Chengru & Peking Library \\
\hline 54 & $\begin{array}{l}\text { Complete Map of Qing } \\
\text { Dynasty }\end{array}$ & 1899 & Atlas of China & $\begin{array}{l}\text { Map of laws and } \\
\text { systems of } \\
\text { Guangxu's reign }\end{array}$ & National Library \\
\hline 55 & Map of World & 1903 & Map of the world & Zou Daijun & $\begin{array}{l}\text { China Map Publishing } \\
\text { Group }\end{array}$ \\
\hline 56 & $\begin{array}{l}\text { Atlas of the Provinces } \\
\text { of Qing Dynasty }\end{array}$ & 1904 & $\begin{array}{l}\text { Map of China (Guangxu's } \\
30 \text { years of Qing Dynasty) }\end{array}$ & Zou Daijun & $\begin{array}{l}\text { National Mapping } \\
\text { Information Archives }\end{array}$ \\
\hline 57 & $\begin{array}{l}\text { Map of Commentary } \\
\text { on the Waterways }\end{array}$ & 1905 & Drainage thematic maps & Yang Shoujing & $\begin{array}{l}\text { National Mapping } \\
\text { Information Archives }\end{array}$ \\
\hline 58 & $\begin{array}{l}\text { Chinese and foreign } \\
\text { map of } 20 \text { th century }\end{array}$ & 1906 & $\begin{array}{l}\text { Atlas of the world } \\
\text { (Guangxu's } 32 \text { years) }\end{array}$ & $\begin{array}{l}\text { Zhou Shitang, Sun } \\
\text { Haihuan }\end{array}$ & $\begin{array}{l}\text { National Mapping } \\
\text { Information Archives }\end{array}$ \\
\hline 59 & $\begin{array}{l}\text { Empire Map of Qing } \\
\text { Dynasty }\end{array}$ & 1908 & $\begin{array}{l}\text { Atlas of China } \\
\text { (Guangxu's } 34 \text { years) }\end{array}$ & Commercial Press & Ningxia Museum \\
\hline
\end{tabular}

Note: The symbol “*” indicates maps published in the "An Atlas of Ancient Maps of China” (Ming and Qing dynasties) 
“Quyutuzhi”. After finishing 250 volumes version, 600 volumes version and 1200 volumes version, a 129-volume unified record and a 100-volume "Maps of states set" were compiled. The 100-volume "Maps of states set" is a combination of maps with topographic contents and mapping styles. Pei Ju was ordered to compile the "Records of Map of Western Countries", containing maps of Western countries.

2.1.4 Jia Dan, a cartographer and Chancellor of the Tang Dynasty, led the completion of the "Haineihuayi Tu"

During the Tang Dynasty (AD 618-907), maps were required to be updated every 5 years. The Library Collection Agencies of Luoyang, the Eastern Capital, include county, country, border, and foreign maps. The state government drew the official map following the court "Ten Road Maps" that included the periods of Empress Wu (AD 684-705), Emperor Tang (AD 712-756), and Emperor Xian Zong (AD 805-820). Li Jifu, the minister, compiled the Illustrated Records of "Yuanhe County".

It took Jia Dan, the cartographer and Chancellor of the Tang Dynasty (AD 730-805, as of Tang Dezong), three decades to compile the "Haineihuayi Tu" (Map of China and Its Neighbouring Countries), covering the Asian continent; this was the first large-scale map of Asia. The map not only conveyed the scale, but was also presented in different colors (ancient counties in black, and current counties in red), which was easy for readers to use.

In the early 8th century, the "Dunhuang star map" was completed (about AD 705-710), using three different painted symbols (painted circles, circles painted yellow, and black dots) to draw more than 1350 stars. This is one of the earliest star maps preserved and contains the largest number of stars on a map in the world (Liang et al., 2016).

2.1.5 "Shouling Tu", by Shen Kuo of the Song Dynasty and "Suzhou stone carved astronomical map" by Huang Shang

Shen Kuo (AD 1031-1095), a well-known scientist during the Song Dynasty, wrote "Mengxibitan" (Dream Stream Essays), a comprehensive compilation of notes that covers the natural science, technology, and social and historical phenomena of China. Joseph Needham, the British science historian, considered the book a milestone in the history of Chinese science. Shen Kuo was also a great cartographer, who compiled "Shouling Tu" (Map of the Counties and Prefectures). In AD 1074, Shen Kuo created a border terrain model onto wax wood. Owing to his skills in using ratio and orientation, this terrain model was quite accurate. It was then made on a larger scale, predating European terrain models of the 18th century by seven centuries (Shen, 1086-1093; Pan, 1975; Yu, 1987).

More than ten types of Song maps have been preserved, including the "Huayi Tu" (Map of China and the Barbarian Countries) of the Northern Song Dynasty, which was China's earliest stone geographic map and drawn according to the "Haineihuayi Tu" by Jia Dan from AD 1117-1125, and carved in AD 1136, modified to reflect the changes in administrative regions. Huang Shang, the Song rites monarch (AD 1044-1130), made a "geographic map" using wood. Completed in AD 1190, the "Suzhou stone carved astronomical map" was the world's first scientific astronomical map with 1440 stars. In AD 1155, Yang Jia, the Minister of the Southern Song Dynasty compiled "geographical maps of 15 countries", which was the earliest printed map, showing regions north of the Yangtze River and south of the Great Wall. The stone map shows typical characteristics of maps from the Song Dynasty, and has there- 
fore retained the old geographical features from before the Song Dynasty.

\subsubsection{Zhu Siben, cartographer of the Yuan Dynasty, and the "Yudi Tu"}

Zhu Siben, the great cartographer of the Yuan Dynasty (AD 1273-1333, guru of Xuanjiao), inherited the mapping method of Pei Xiu, Jia Dan, and Shen Kuo, and not only summarized the geographic achievements since the Tang and Song dynasties, but also obtained a lot of current mapping data by himself. It took Zhu a decade to draw the Yudi Tu (Terrestrial Map)" (AD 1315), which marks the coming of age and perfection of ancient Chinese cartography.

Another two famous cartographers of the Yuan Dynasty were Li Zemin, who produced the "Shengjiaoguangbei Tu", and Qing Jun, who produced the "Hunyijiangli Tu" and "Guangyujiangli Tu". According to the "Shuidong Diary" of the Ming Dynasty, the "Guangyujiangli Tu" combined historical evolution and political zones. The map shows the area north of the Yellow River, to Yakutsk of Soviet Union, and west from Tianshan Mountains, India, Pakistan, to the border of Afghanistan. This map is mainly about "Xia" (China), which also includes other neighboring countries.

In 1959, Joseph Needham analyzed ancient maps of the Yuan Dynasty, stating that during "the 14th century to the mid-15th century, on Europe and Arab maps, the tip of Africa was often painted pointing east by mistake, but in the first 'Guangyu Tu' (Enlarged Terrestrial Atlas) published in 1555 and made by 'Yudi Tu', the tip of Africa points to the South, which means that Zhu Siben had drawn up like this since 1315. So, Chinese cartographers of the Yuan Dynasty are the apparent winners."

\subsection{Ancient maps of the Ming Dynasty - integration and development of Chinese and Western cartography}

During the early Ming Dynasty, the Chinese maritime industry peaked under Emperor Zhu Di's advocacy. During AD 1405-1433, Zheng He led the world's largest fleet and was the first to complete ocean sailing before the West, and also promoted offshore sailing. Sailing maps in the Ming Dynasty formed a series, including the famous "Zheng He's Voyages" (Charts of Zheng He's Voyages), including "Led Star Sailing Maps", "Voyage Plan", "Nautical Needle Road Map”, "Sailing Guide Map”, and "Southern Sea Road Map”(Liang, 2016). All these provided the newest information that allowed for the creation of a complete world map in China before world map was made in the West.

During the early Ming Dynasty in AD 1389, the "Daminghunyi Map" was compiled by Chinese without other foreigners' help, which has become a national treasure. In AD 1418, the "World Zhufan Tribute Knowledge Map", a world map consisting of two hemispheres, was completed. This was before a similar map was completed by the West (Liu, 2009).

A century later, Luo Hongxian, the eminent cartographer of the Ming Dynasty (AD 1504-1564) compiled the first comprehensive atlas of ancient China, the "Guangyu Tu". This was based on Zhu Siben's "Yudi Tu”, with reference to Li Zemin's "Shengjiaoguangbei Tu”, Xu Xiyu's "Nine Borders Small Map", Tang Yushi's “Trilateral Four Towns Map", and 14 types of maps from Yuan and Ming dynasties. Based on the map sheet size and regions, and using different scales such as $40 \mathrm{li}$ (1 li equals 500 meters), $100 \mathrm{li}, 200 \mathrm{li}, 400 \mathrm{li}$ and $500 \mathrm{li}$, Luo divided the "Yudi Tu" into 40 smaller maps. He also created a legend for 24 
types of commonly used symbols, with 17 symbols representing different settlement functions. The "Guangyu Tu" is known around the world. The "grid scales of li" map arose after the Ming and Qing dynasties, and was mostly based on the "Guangyu Tu". Matteo Ricci, an Italian missionary, completed the "Huaguotuzhi" in AD 1552, which is also a "Guangyu Tu" with a French translation edition.

In 1601, Matteo Ricci arrived in Beijing and compiled the Map of the World, which was used widely, combining the "Universal map" by Audrey Alice, an Austrian geographer, and Luo Hongxian's "Guangyu Tu". For the first time the "fusion of Chinese and Western maps" occurred, spreading geographical knowledge in both hemispheres, to the poles, across five continents, and five belts. Later, Ricci translated the "Universal Map" into Chinese. Chinese included a painting in the middle of the map, and changed its name to "Shanhaiyu Tu", which has been printed 12 times. It was finally renamed the "Universal Geographic Country-wide Map", and was regarded as a world famous geographic work (Qi, 2016).

"Wubei Zhi" (Treatise on Armament Technology), which was finished in the Ming Dynasty (AD 1621) by Mao Yuanyi, has 240 volumes, more than 200 million words, and 738 drawings, making it one of the most ambitious and comprehensive war books of ancient China. When Mao Yuanyi discussed the ancient "Fang Yu, the town garrison, coastal defense, river defenses, and sailing", he used an "illustrated"-mode, displaying in detail the "geographical situation, frontier forbidding, land and sea enemy, bodyguard defence system, governors supervision department and other contents". The "Zheng He's Voyages", the Chouhaitubian (Illustrated Seaboard Strategy), "Haifangtulun", and a number of other precious maps have been preserved, which are undoubtedly one of the major merits of Mao Yuanyi and "Wubei Zhi".

During the late Ming Dynasty, Xu Guangqi and others drew the "barrier stellar map", which is the most complete star map (1812 stars) with yellow and red color. This map shows that an ancient Chinese astronomical map in the mid-17th century was still considered to be at an advanced world level.

\subsection{Ancient maps of the Qing Dynasty - map modernization matures}

The Emperor of the Qing Dynasty attached great importance to the Western cartographic technology used in the preparation of Chinese and world maps. Emperor Kangxi hired Nan Huairen, a Belgian missionary, to preside over the "Kunyu Map" in AD 1674. In AD 1767, Emperor Qianlong hired Jiang Youren, a former French missionary, to revise the "Full Kunyu Map". The "Nan Huairen's Map" is surrounded by 14 sections of astronomical description. The "Jiang Youren's Map", using the then-new world map and a map of China, summarized the survey results of world geography of the 16-18th centuries, where bright orange was used to mark "Taiwan and its affiliated islands (the Diaoyu Islands included) and mainland China", comments of posterity his "history of China called the world's mapping and synthesizer masterpiece" (Liang et al., 2015).

Emperor Kangxi hired Lei Xiaosi, a French missionary who was a proficient cartographer, and six others to complete China's first country map, known as the "Huangyu Full View Map". This was produced in AD 1718 and later translated into Manchu and French.

This map was recognized internationally and is considered to be "not only the best in Asia, but also better and more accurate than all the maps of Europe" (J. Needham, 1976). Emperor 
Kangxi ordered craftsmen to carve the "white gold with Chinese drawing desk" that is collected in the Forbidden City in Beijing. However, the "Kangxi Huangyuguanlan Tu" (Map of China in the Kangxi Reign), which spent huge amounts of money drawing and on behalf of world's leading, was long term collected within the Forbidden City, thus it has not played a role in economic and social development of China. In contrast, the Western missionaries, who participated in mapping, brought the map abroad and published in the Western world. As a result, for a long term the West understood the geography of China better than the Chinese themselves.

From AD 1756 to 1760, Emperor Qianlong compiled and printed 104 "Qianlong thirteen row copperplate maps" with a supplement of Xinjiang and Tibetan data, which makes it the most complete map of the history of Chinese administrative territories in history.

After the first Opium War in 1842, Wei Yuan accepted Lin Zexu's commission to compile the "Haiguotuzhi" (Records and Maps of the World) based on the "Four Continents". The book includes 880,000 words, 75 maps, covering history, global, continental, regional, and country maps. "Haiguotuzhi" is China's first modern world atlas, integrating Chinese and Western maps with records, which had a great impact on the world (Yu et al., 2010). During the Tongzhi period of the Qing Dynasty, Hu Linyi and others compiled the "Daqing Tu" (Atlas of the Great Qing Dynasty) with 31 volumes. It was published in 1863 and marked in detail the boundaries of successive dynasties, and described the mountains, cities, frontiers, and other markers more accurately. It was circulated widely in the late Qing Dynasty. The "ancient geography map" was printed and published during the Qing Dynasty, and is a Chinese historical map with detailed content and reference value. It showed detailed plotting of the territory of the Dynasty, the administrative districts, and the location of mountains, using a two-color (red and black) overprint, placing history and modern names by comparison. Based on the mapping data of all the provinces, the "Guangxu Huidian Map" marked the coming of age of Chinese modern mapping technology (Liang et al., 2016).

In AD 1875-1911, along with the Westernization Movement of the late Qing Dynasty, multiple private mapping institutions were created. This promoted the rapid development of various types of useful maps, increased the enrichment of the thematic content, made significant progress in mapping technology, introduced the use of latitude and longitude mapping methods, color printing, followed by official publication, benefiting people, and marking the rapid development of the Chinese map market and the growth of modernization. However, from the Ming to the Qing Dynasty, many maps were drawn with the traditional perspective view, with neither position nor latitude and longitude lines. In addition to the geographical details, such as trees and other natural landscapes, there were many interesting cultural features, such as houses, streets, villages, and even pedestrians, bullock carts, and deer. These maps are colorful, vivid, and like a fine art. Although these maps were often drawn using the plane-bound facade painting method to emphasize the image and mood, there are captions around the figure to convey the aim of the map. The coastal defense maps and most offshore navigational maps used the scroll type, the painters' onboard observational drawing method, which shows that ancient Chinese cartography had a practical approach (Jiang et al., 2016; Pi et al., 2016).

\subsection{Ancient maps of other countries}

According to history books from the Tang and Song dynasties, interactions between neigh- 
neighboring countries led to ancient maps spreading to Korea, Japan, and other countries. In the early 15th century, Lee Hui, a Korean, took two maps of the Yuan Dynasty (the "Shengjiaoguangbei Tu" and "Hunyijiangli Tu"), and co-edited them into the "Hunyijiangli Tu of capitals of successive dynasties". Copies of this map were widely circulated after it was introduced into Japan in AD 1422.

After searching the British Library and other libraries, archives, museums, churches, monasteries, and even private collections in more than ten European countries, Li Xiaocong, a Chinese cartographer, identified ancient maps of these countries, some of them very precious. For example, maps were found in Seville, Spain, and France, where archives included the "Gujin Xingsheng Tu" re-carved in the 34 years of Jiajing's reign in the Ming Dynasty (AD 1555).

The Selden Map of China was preserved in the Bodleian Library of Oxford University. The British Library collection in London contains more than 200 ancient Chinese maps, of which over 100 are military camp maps from Jiangsu, Zhejiang, Fujian, Guangdong, and other places sealed with the red seal of the local authorities. During the Ming Dynasty (AD 1623), missionaries Yang Shimano and Long Huamin painted a colorful globe on a lacquered frame with a 59-cm diameter. The British Royal Geographical Society, the Asia Society, and the public archives collected hundreds of Chinese maps. The British National Archives have a collection of maps during the period when the Qing military troops repressed the Taiping rebellion.

The French National Library has a collection of paintings from the Ming and Qing dynasties that includes more than 40 valuable maps, such as those of the years of Wanli and Tianqi of Ming Dynasty (1603 to 1626), Korea copy of silk painted map, "Yudi Tu" (a map of China), and missionary Ferdinand Verbiest's compilation of the "Kunyu Map (A Complete Map of Qing Dynasty)". The Vatican Library collection includes ancient Chinese maps covering the period from middle Ming Dynasty to early Qing Dynasty with the participation of Western missionaries, such as the Ricci's "Universal geographic country map", the Johann's compilation of Luoya Valley revision of "total northern and southern equatorial star map", Boym's "China's overall geography map", and Sambiasi’s "Kunyu Map". The Italian Geographic Society's collection includes a Ming Dynasty painting of 16-format "Gansu town map", and others, including more than 200 Chinese maps, and more than 400 maps of areas inhabited by the minority nationalities and the style of dress of daily life of local people of Guangdong, Guangxi, Yunnan and Guizhou during the reign of emperors Qianlong and Jiaqing in the Qing Dynasty. The German collection contains hundreds of pieces from the Qing Dynasty during the Tongzhi and Guangxu years showing Shandong and Zhili (now Hebei) provincial governments, states, districts, counties, rivers, the Great Wall, training camps navy of the Yangtze, and other thematic maps. The Bavarian State Library in Munich has a collection of the scroll engineering map of the Yellow River. The East Asian Institute at the University of Munich regarded the China ancient maps which were purchased from Dr. Boshiman as special collections. These maps were collected when he traveled to China in the early 20th century (Li, 1996). There are ancient Chinese maps stored in the Geography and the Map Division Special Collections Room of the Library of Congress. The collection also includes many traditional drawn maps and the Library now provides a high-definition 
scanning electron map of network services, including maps of the world, foreign maps, areal maps showing provincial, government, state, hall, counties, and thematic maps of cities, palaces, gardens, and mausoleums.

The Watson Library collection unit at Cornell University, Harvard-Yenching Library, and the Yale University East Asian Library also collected many ancient Chinese maps.

\section{Heritage of Chinese cartography}

Chinese cartography was founded on Pei Xiu's six principles of cartography. Shen Kuo (Southern Song Dynasty) then proposed the "seven laws of cartography" to improve the "six principles of cartography" by combining them with his own practice which includes Fenlu (Scale), Zhunwang (Direction), Yarong (Frontier), Bangyan (Distance), Gaoxia (Height), Fangxie (Slope), Yuzhi (Bending) and Chinese characteristics: "Grid scales mapping method", "impressionism/realism", "Star-Aiming Charts for Crossing the Oceans" and "astronomical geodetic latitude and longitude length measurement findings".

\subsection{Pei Xiu's theory (the six principles of cartography)}

The "Book of Jin Dynasty (Pei Xiu's Biography)" lists the six principles of cartography. The first principle is Fenlu, to reflect the ratio of size, length and width, for example the map scale; the second is Zhunwang, to determine the orientation relationship between features; and the third is road distance (Daoli), to determine the distance between the two places.

Gaoxia, the fourth principle, is height; the fifth is Fangxie; and the sixth is Yuzhi. Each of these final three principles should be used with consideration of local conditions. Needham once translated Pei Xiu's "Yugong geographical map" in full, in which "Zhunwang, adjust feature's position" was translated to "Drawing rectangular grids (Zhunwang), is one way to correct the relative position between each section of the map, including three elements: position, distance, ratio". According to Xin Deyong's theory, when drawing the map, the ancients needed to figure out how to locate the geographic features on the ground to a nearly horizontal plane ... it means that it is necessary to transform the three-dimensional terrain into plane with the same datum, based on 'flat horizontal projection', and thereby correct the relative positional relationship between the geographic features. This should be the meaning of Pei Xiu's “correct each other's positive". Pei Xiu's "Zhunwang" means the geographic coordinates. However, we should emphasize that with regard to the geographic coordinates mentioned here, in the sense of mapping principles, the first refers to the actual coordinates of the feature in the horizontal projection plane, and the second is to place it onto a map. Liu Gang, an ancient map collector, conducted an in-depth study of the two hemispheres circular projection method used for producing "Tianxiazhufanshigong Tu (map of the world)", and Liu Gang stated that "Zhunwang" is "discriminate orientation", and "correct position" can guide the cartographer to "Map along the left and right sides aligned with Polaris", "Grid scales method can evolve into a trapezoid, until it becomes a circle" (Xin, 2007; Wu, 2010).

\subsection{Shen Kuo's mapping method (seven principles)}

Shen Kuo (AD 1031-1095) was an eminent scientist of the 11th century. He made an out- 
standing contribution to astronomy, geography, and cartography. According to historical records, 4 years before the compilation of the "Shouling Tu" (Map of the Countries and Prefectures) (AD 1076), Shen Kuo had taken charge of astronomical observation, insisting that the stars be observed continuously for more than 3 months, and drew over 200 circular astronomical maps. Shen Kuo stated that, using "the format of an astronomical figure to draw geographical maps, just the stars of heaven should replace the Earth's counties". This made Shen Kuo break with traditional thought, applying a radial coordinate to the astronomical map, a unique solution to relaying the appearance of the Earth onto a planimetric map. In addition, for the first time, he incorporated a compass into a map and achieved map digitalization. These cartographical achievements remained influential for a long time after.

In the famous paper of Shen Kuo on cartography, although li numbers (distance) are shown on the previous maps, distances are normally measured by steps along the road. The road might be straight or have bends, so after finishing mapping, li number marked on the map cannot be consistent with the real distance. Therefore distance should be recalculated according to the four directions of the straight-line distance map, viewed like a bird flying directly to its destination and unaffected by geographic elevations. Shen Kuo put forward seven principles of mapping (Fenlu, Zhunwang, Yarong, Bangyan, Gaoxia, Fangxie, Yuzhi) when he drew the "Shouling Tu". Shen Kuo explains the method as: "take the distance a bird flies, to get the real distance, which means that using this method, even after losing the maps, you can immediately draw the map correctly, no slightest deviation to reality. "(Pan, 1975; Yu, 1987)

\section{3 "Mapping by drawing grid of $l i "$ - the projection method of early Chinese car- tography}

When maps first began to appear, methods based on the drawing of grids are likely to have been implicit in the mapping process. This is because when expressing position and distance, grid scale of $l i$, one of the most simple laws of mapping, will naturally emerge, which is also a more conducive law of copying the map. Pei Xiu was in charge of "Sikong" positions (Minister of Public Works), and one of his duties was to seek accurate management law of land use. When he discovered numerous errors in previous maps, he tried to explore new ways of mapping. This resulted in the proposal of the major cartographic theory of the six principles of mapping. He improved the "Mapping by drawing grid of $l i$ " technique in the production of the "Terrain Map".

Pei Xiu said: "If there is no Daoli, Fangxie, or Yuzhi to correct the length of the pathway, there must be large differences compared to the real distance". These six principles should all be considered. The principle of Fenlu determines long and short distance; Zhunwang determines relative position of features; Daoli represents path, which means that only the horizontal distance between two points which is a straight line can be uniquely identified, can point to a certain direction, and is associated with scale. The journey between the two places depends on the terrain inclination and curvature of the road, regardless of the scale and the direction. The actual distance between two places is the distance on the map divided by the scale, which was called "bird flies". Only the right grid scale can ensure the correct distance, without causing a change in position and direction. Owing to the fact that a sphere cannot be 
cannot be fully extended onto a plane, direction distortion of the drawing square map is inevitable. However, Pei Xiu's drawing work is divided into the small scale: "100 miles square", and it is difficult to find the angle deformation or distance deformation in such a small area.

Pei Xiu's principle of "Zhunwang" cannot be completely likened to the modern concept of direction or orientation. This can only be achieved through the "grid scale". The correct position and direction of the "grid scale" is equivalent to the right of "Zhunwang". The method of determining the location in the grid scale method is similar to the modern polar coordinate method. For this reason, later generations of cartographers have used the trapezoid to make "Zhunwang" more accurate. When compared with the grid scale equidistant cylindrical projection, the analogy can be a trapezoidal conic projection, which in turn can evolve into an azimuthal projection. However, "six principles of mapping" and "Diary painting party" were completed under the guidance of a more accurate and scientific Cartesian coordinate system.

It is remarkable as Pei Xiu said, that "The real elevation angle is considered by Gaoxia". In the ancient map, height of the summit with road through would be marked which shows the height difference between mountain summit and ground surface. The degree refers to the elevation angle of the mountain when looking up at the angle on the foot of the mountain. According to this angle, the horizontal distance could be calculated which is called the number of "Jinglu". In order to expand the earth to plane, he should have a preliminary concept of projection. However, he did not use graticule, but rather "grid" technology. Pei Xiu's "Terrain Fangzhang Map" adopted "grid" to divide the "world" into "many grids". Using "pantograph" principles and methods of wood working, each of the "grid" was zoomed to the paper, projecting the Earth's surface to horizontal surface. With respect to the spherical surface, Pei Xiu's "grid scale" method can be regarded as a graticule, the Chinese-style equidistant cylindrical projection (grid scale). Emitted line from the Earth's center to the surface, projected to the plane, and then stitching these small grids into large flat map, which produced a grid scale map can be easily converted into latitude and longitude map based on the "equidistant cylindrical projection".

\subsection{Impressionism/realism - China's traditional mapping art}

Ancient Chinese maps, in a long time, describe a variety of ground objects using "impressionism", "realism" or these two methods combined together, which was greatly influenced by Chinese ancient painting technique or art. "Impressionism" is the essence of drawing, while "realism" is required for scientific mapping.

Drawing maps from memory or by listening to others is more impressionistic, but it is impossible to estimate the accuracy of these maps. The realistic scene method is also influenced by the highly "realistic" approach of the ancient tradition of Chinese palace painting. This method is common in traditional Chinese impressionistic maps, which describe landmark objects using realistic symbols.

Advantages of the relative scenery were that as long as the features on the map correspond with objects, the current location can be determined and the way forward can be chosen, which has a good artistic and practical effect. Ancient drawing methods were used in a 
variety of ancient land maps, charts, military maps, water conservancy maps, city maps, and diagrams showing places of historic interest.

Therefore, it is thought that "under China's unique ideas and special living conditions, China's traditional maps are produced to be map art with special knowledge value" (J. Needham, 1976). In particular, scenic ancient maps that have been preserved to the present day could be described as graceful, vivid, and elegant; while they, to some extent, reflect the geographic information distribution, and also have the benefits of aesthetic beauty. They are effectively a combination of traditional Chinese science and culture, reflecting the same strain of traditional Chinese art, perhaps providing a better map model to balance between modern scientific maps and art (Jiang et al., 2016).

\section{5 "Star-Aiming Charts for Crossing the Oceans" - China's first invention in the world history of navigation}

The star-aiming measurement method is a useful way to determine the ship's position by measuring the height of the stars. It was invented by an ancient Chinese navigator by calculating the geographic latitude based on the height of the stars and determining the heading direction of the ship with a specific vessel water compass. The star-aiming measurement method was first used in Zheng He's marine navigation, and the "Charts of Zheng He's Voyages" indicate data for star-aiming, and is also equipped with four special "Star-Aiming Charts for Crossing the Oceans". The orientation of this type of star-aiming charts is from the north down to the south; a sailing yacht is painted on the central square of the chart, surrounded by boxes showing the retractor used, and indicates the position, star names, and height of the aiming star. The "Star-Aiming Charts for Crossing the Oceans" appeared in the 15 th century, with the water compass invented by the Chinese to achieve ocean navigation, an initiative of the Chinese people. These basic principles of mapping and navigation technology still merit further exploration and learning.

According to historical records, the main tool of astrology is the star-aiming board. It is used to measure the height of the stars from the horizontal instrument; the principle is equivalent to today's sextant. The star-aiming board had a total of 12 square boards, star plate led a total of 12 square board, side length from 1 to 12 means finger, while a small ivory square plate with gaps in the four corners. In use, holding the center of the plate with left hand, arms straight forward and looking at the sky, the lower edge of the wood stick to the horizon, the upper edge of the alignment Polaris, thus obtained the elevation angle of stars represented by the mean angle and the finger. One finger is equal to four corners, about 1.9 degrees. Elevation angle of Polaris is the latitude of the ship's position. In the Ming Dynasty, the constellations which are used in star-aiming method included the North Star, Vega Star, Cloth Division stars, level star ( $\alpha$ star constellation on bottom of the boat), the Big Dipper, canopy stars, and lanterns bone star(Liang, 2016).

\section{Cultural value of ancient maps}

According to the "Protection of the World Cultural and Natural Heritage" by the UNESCO General Conference and the "Convention on the Protection of Intangible Cultural Heritage" 
and related documents, as well as relevant provisions of the "Cultural Relics Protection Law in People's Republic of China", the generalized culture value of the estate, including ancient maps, mainly reflects three aspects: the historical, artistic, and technological values. Ancient Chinese maps saved in famous mapping collections have a high cultural heritage value. As the protection and use of the world cultural heritage has entered the modern scientific and technological support period, the value of cultural heritage of the ancient Chinese map should be better protected, researched, and used.

\subsection{Rarity value}

"Rare is precious" according to Tan Qixiang, the famous professor of historical geography, who also noted that "Ancient Chinese maps handed down may be less than one percent, even one-thousandth" (Cao et al., 1997). The number of ancient maps is small and spread across the world, making the existing copies of ancient maps particularly precious. Some examples of these include the "Suzhou stone carved astronomical map", which remains China's first scientific astronomical map forever; the stone carved "Huayi map" (Map of China and Barbarian Countries) and "Map of Yuji" kept the old figure of Asian maps drawn in the Yuan Dynasty, which was already lost; "Daminghunyi Tu" has become one of the greatest treasures of the Library; the "Charts of Zheng He's Voyages" and the "Star-Aiming Charts for Crossing the Oceans" represent the leading position of the Ming Dynasty in oceangoing voyages; and "Cher Teng's Chinese Map" shows China's first sailing map of the Ming Dynasty.

\subsection{Practical value}

Different types of ancient maps show the Earth, celestial, marine, geology, geography, environmental evolution, national and regional history, and spatial distribution of political, economic, military, cultural characteristics, sailing, travel, business, education, research, agriculture, industry, and other human activities. The ancient Chinese chronicles, in particular, are often accompanied by maps, monographs, encyclopedia or other forms, and provide richer information, and a wide range of applications.

The recent major historical and cultural CCTV documentary "Forbidden City" used the "Yangtze postscript device map" of the Ming Dynasty provided by the National Mapping File Archive, the "General View of Xinjiang Mountains", the "Grand Canal Map", and the "years to dominate the world map" of the Qing Dynasty. In the episode "landscape", with the "years to dominate the world map" on the screen, by combining ancient maps with modern animation processing, demonstrated that under the control of the Emperor Yongle, Cabinet and six departments responsible for their own responsibilities, national executive orders were delivered from the Forbidden City, through the 1936 Inns of the country and post road with a total length of $143,700 \mathrm{~km}$, then to every corner of the empire. Without these old maps, the "Forbidden City" documentary viewing will be far less. Therefore, building a technology system using the Internet combined with ancient maps will help more people to easily understand and use old maps, and will allow the full potential of ancient maps to be realized.

\subsection{Historical value}

Ancient maps are part of the historical and cultural heritage. Maps have a dual role of tangi- 
ble and intangible cultural heritage. As tangible cultural heritage, a 1600-year-old scientific map provides a rich variety of the history of human activities and environmental changes, such as the evolution of countries and regions, the world's political, economic, military, and cultural evolution. Ancient maps have become an important source of information that people understand and use to study the history of change.

As an intangible cultural heritage, ancient maps have played an indispensable role in broadening the vision of Chinese people, promoting international exchange, and social progress. The major social effect it produces could not be substituted by any other books. For example, "Haiguotuzhi" (Illustrated Records of Maritime Nations) became the first tuzhi (Annals of maps) that Chinese began to see the world, and Toshio Otani summed up the "Illustrated Records of Maritime Nations" as Japan's contribution to the promotion of its three revolutionary reforms (Ye et al., 2016).

The territory of ancient Chinese maps shows a significant historical role. For example, the sailing series of the Ming Dynasty today remain as precise documented evidence that the Diaoyu Islands and the South China Sea Islands belong to the Chinese territory. The "Qianlong thirteen row copperplate maps", "Daqingyitong Tu" (Atlas of the Great Qing Dynasty), and others provide the most compelling evidence that the dominion of Xinjiang, Tibet, Mongolia, and vast homeland sovereignty, including Sakhalin, belong to China. Territorial boundary negotiations between neighbors were often based primarily on historical maps.

\subsection{Scientific value}

Pei Xiu's six principles of cartography, as the main content of Chinese ancient cartography, have guided the completion of the tens of thousands of scientific works of ancient maps. Ancient Chinese maps with their own characteristics have provided important scientific value to the development of cartography worldwide. So far there are still people exploring how to combine artistic characteristics of Chinese ancient maps with the Western mathematical characteristics to enhance artistic expression of the map.

The scientific value of ancient maps is also reflected in how the map shows scientific achievement. These include the confirmation of star positions in astronomical maps, the political or financial centers of capital accumulation and movement routes of the world map, land and anti-military map expression, elements of coastal defense, flood prevention works on the river, dike, gate and channel layout on water resources and river work diagram, residential administrative map of transport routes, boundaries of administrative divisions, symbols design and element expression, inns of Silk Road map, the distribution of the Post Road, and sailing route design on nautical charts demonstrated the wisdom of the ancients and scientific understanding of nature and human world. Thus, a variety of ancient maps become the historical data of scientific research.

\subsection{Artistic value}

The painting of impressionism/realism in Chinese ancient maps is of great artistic value. Figures 1-4 demonstrate that the "Yellow River Map", the "Grand Canal Map" of the Qing Dynasty (Pi et al., 2016), the "Map of Summer Resort", and the "Complete Map of Tianjin Urban and Rural Bao-jia System" are all masterpieces of ancient artistic maps. 


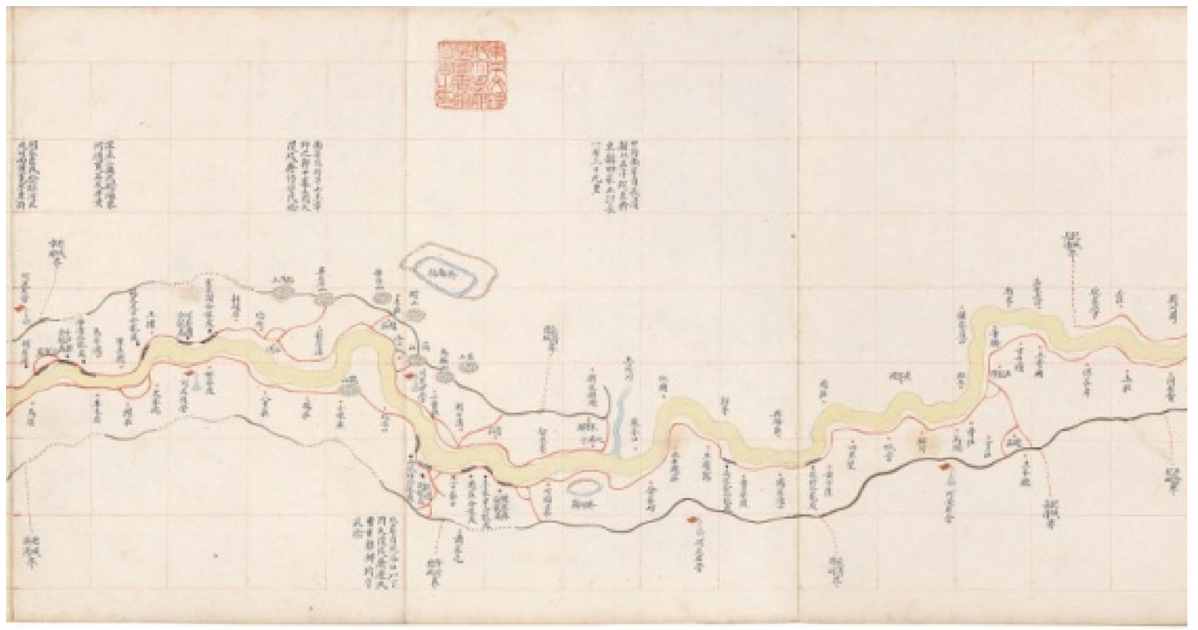

Figure 1 Yellow River Map (part)

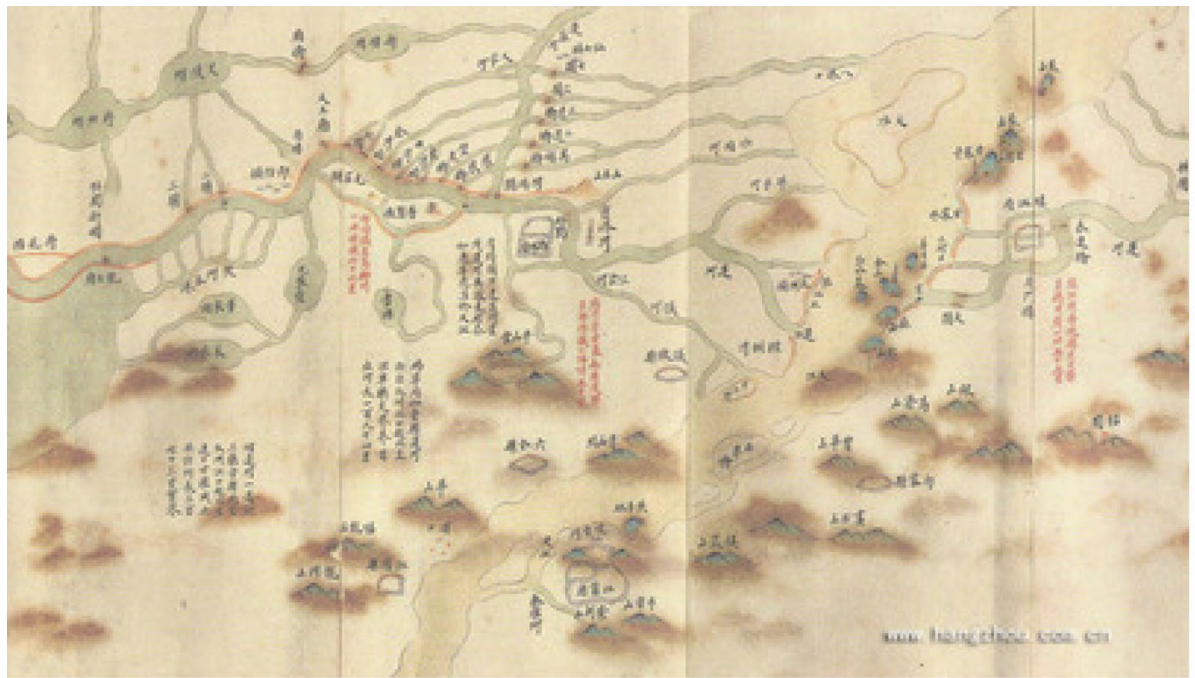

Figure 2 Grand Canal Map (part)

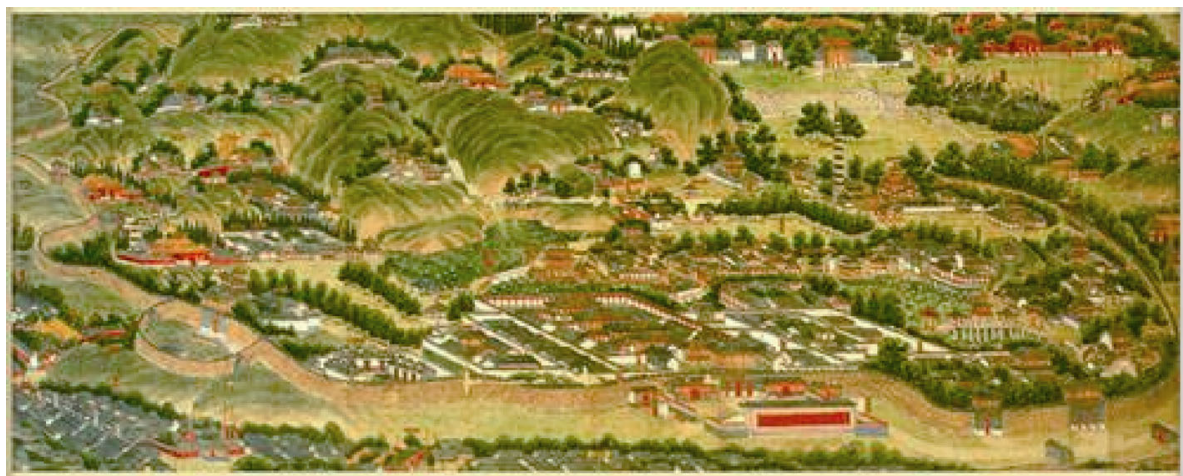

Figure 3 Map of the Summer Resort (part) 


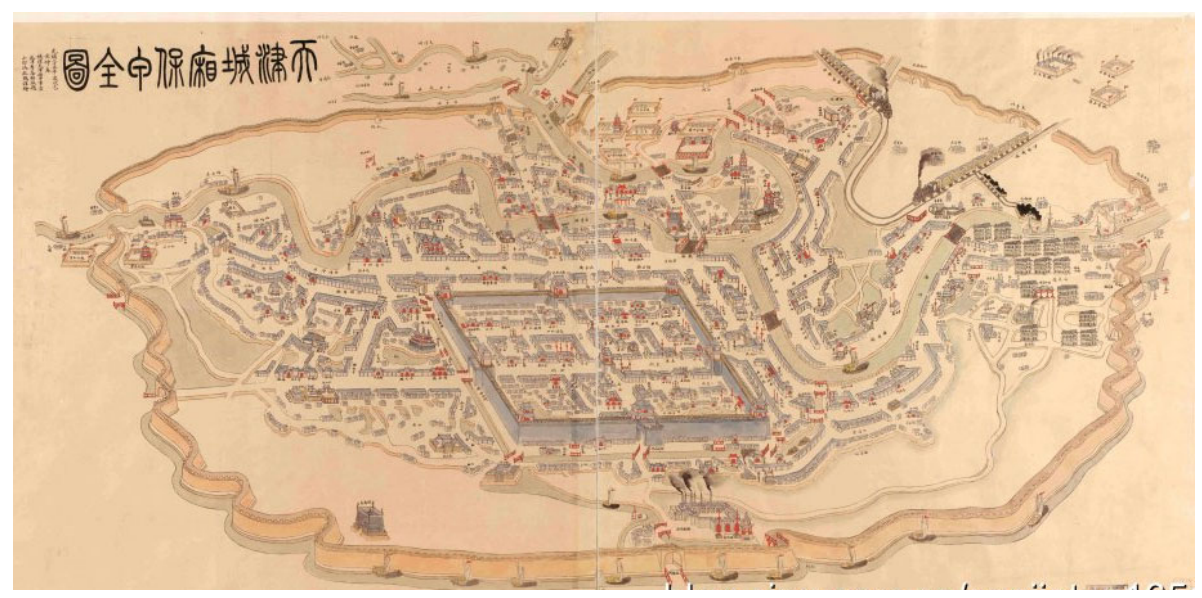

Figure 4 Complete Map of Tianjin Urban and Rural Bao-jia System

\section{Results}

This paper reviews the scientific heritage of ancient Chinese maps collected in domestic and foreign institutions. Many of the ancient Chinese maps have been made using the "annals of maps", "encyclopedias", or "monographs". They provide extremely rich illustrated records of China and the world including "history, politics, culture, territory, military, science and technology, education, navigation, trade, environment, water, roads, cities, places of interest, and historic sites" and other historical traces. Maps are an important part of the world cultural heritage of cartography, and the heritage of ancient maps should be studied and reused. It is imperative to strengthen domestic and international cooperation, modeled on the European Union's "2020 Plan" to unite together, for the heritage and preservation of ancient Chinese maps, to promote the re-use of historic maps, and to fully make use of the potential value of map legacy.

Some of our recommendations are as follows:

(1) Establish a national project of map heritage research, organize relevant experts with "the evolution of the environment, climate change, global security, open integration, human harmony", and other major scientific issues, and conduct thematic map legacy application with the greatest concern to humans;

(2) Create a web services platform, develop service mechanisms to ensure asset protection, and promote the use of heritage, to provide more opportunities for people to participate in the research and use of the map heritage;

(3) Unite map collections to create mechanisms of cooperation to propose map heritage list classification criteria for the registration of maps, and establish a system to share the ancient Chinese map heritage list sharing database system;

(4) Actively promote the implementation of the map collections in the completion of ancient maps, repairing, and HD scanning, to automatically add to the heritage of ancient maps, increasing the preservation and sustainable use of the maps.

\section{References}

Cao W R et al., 1990a. Ancient Chinese Atlas (the Ming Dynasty). Beijing: Cultural Relics Press. (in Chinese)

Cao W R et al., 1990b. Ancient Chinese Atlas (the Warring States Period to Yuan Dynasty). Beijing: Cultural 
Relics Press. (in Chinese)

Cao W R, Zhen X H, Huang S Z et al., 1997. Ancient Chinese Atlas (the Qing Dynasty). Beijing: Cultural Relics Press. (in Chinese)

Jiang L L, Qi Q W, Zhao K, 2016. The characteristics and value of the Yellow River and Beijing-Hangzhou Grand Canal map in China's Ming and Qing period. Journal of Geo-information Science, 18(1): 39-48. (in Chinese)

Li X C, 1996. European Collection Record of Chinese Ancient Map. Beijing: International Cultural Publishing Group. (in Chinese)

Li X C, 2004. Library of Congress Holding in Chinese Ancient Maps. Beijing: Cultural Relics Press. (in Chinese) Liang Q Z, Liang X, 2016. The cartography value of "Haiguotuzhi”. Journal of Geo-information Science, 18(1): 49-56. (in Chinese)

Liang Q Z, Qi Q W, Liang X, 2015. The main achievements and characteristics of the ancient world map of China. Journal of Geographical Sciences, 70 (8): 1351-1360. (in Chinese)

Liang Q Z, Wang J, 2016. Main achievements and contributions to explore astronomical figure in ancient China. Journal of Geo-information Science, 18(1): 14-20. (in Chinese)

Liang X, 2016. To explore the chart feature of Ming Dynasty in China. Journal of Geo-information Science, 18 (1): 32-28. (in Chinese)

Liu G, 2009. The Ancient Map Password. Guilin: Guangxi Normal University Press. (in Chinese)

Liu Z W, 1995. Chinese Ancient Map Selection. Beijing: China Esperanto Press. (in Chinese)

$\mathrm{Lu} \mathrm{L} \mathrm{Z,} \mathrm{2008.} \mathrm{Pi} \mathrm{Xiu} \mathrm{and} \mathrm{the} \mathrm{theory} \mathrm{of} \mathrm{six} \mathrm{principles} \mathrm{of} \mathrm{cartography.} \mathrm{The} \mathrm{history} \mathrm{of} \mathrm{Cartography.} \mathrm{Land} \mathrm{Resources,}$ (2): 54-57. (in Chinese)

Needham J, 1976. Chinese History of Science and Technology. Beijing: Science Press.

Niu R C, 2014. Culture and values of map. Surveying and Mapping Science, 39(12): 3-7. (in Chinese)

Pan F Y, 1975. The important contribution on geography of Kuo Shen through "Mengxibitan". Journal of Nanjing Normal University, (1): 13-17. (in Chinese)

Pi L F, Zhang A, Xia X L, 2016. The artistry discussion of ancient Chinese map. Journal of Geo-information Science, (1): 96-105. (in Chinese)

Qi Q W, 2016. The exploration of Chinese ancient modern maps. Journal of Geo-information Science, (1): 2-13. (in Chinese)

Shanbentezang Group in Yutu Department of Beijing Library, 1997. Ancient Map to Record. Beijing: The National Library Press. (in Chinese)

Shen K (Song Dynasty), 1086-1093. Mengxibitan. Beijing: Cultural Relics Press. (in Chinese)

Sun J G, 2012. The Chinese Ancient Maps Record of Library of Chinese Academy of Sciences. Beijing: SinoMaps Press. (in Chinese)

Toshio O (Japan), 2012. The impact of "Haiguotuzhi" in Japan. "Haiguotuzhi" and Cultural Exchange between China and Japan Research, (33): 51-52. (in Chinese)

Wang Q J, 2007. The Research Literature Integration of Cartography History of China. Xi'an: Xi'an Map Publishing House. (in Chinese)

Wu J B, 2010. Six cartography principles and remember the cross party of Xu Pei. History (Beijing), (4): 67-81. (in Chinese)

Xin D Y, 2007. Accurate Definition. Fourth Album of "Kyushu". Beijing: The Commercial Press. (in Chinese)

Yang Q, Guo Y, 2003. The ancient map making history of China. Books and Information, 72-75. (in Chinese)

Ye Y J, Zhang A, Qi Q W, 2016. Exploration of the features and values of modern Chinese provinces and regions map. Journal of Geo-information Science, (1): 57-67. (in Chinese)

Yu C, 1998. The Chinese Ancient Treasure Map Selection. Harbin: Harbin Map Publishing House. (in Chinese)

Yu C, Liao K, 2010. History of Chinese Cartography. Beijing: China Surveying and Mapping Press. (in Chinese)

Yu L Z, 1986. Yu Qing, one of the outstanding cartographers of Yuan Dynasty. The Voice of Dharma, (3): 43-46.

Yu L Z, 1987. The outstanding achievement of quantitative graphics of Song Dynasty represented by Kuo Shen. Journal of Nanjing Normal University, (3): 91-94. (in Chinese)

Zheng X H, 2005. The Ancient Atlas (City) in China. Xi'an: Xi'an Map Publishing House. (in Chinese) 